\title{
The phantasmatic logic of e-government and the discourse of innovation in Cape Verde
}

Osíris Luís da Cunha Fernandes ${ }^{1}$

Fernando Gomes de Paiva Júnior 2

Nelson da Cruz Monteiro Fernandes ${ }^{3}$

Marconi Freitas da Costa ${ }^{3}$

1 Instituto de Tecnologia de Pernambuco, Recife / PE — Brazil

2 Universidade Federal de Pernambuco/ Programa de Pós-Graduação em Administração, Recife / PE — Brazil

3 Universidade Federal de Pernambuco/ Programa de Pós-Graduação em Gestão, Inovação e Consumo, Caruaru / PE — Brazil

This study aims to deepen the reflections on E-government (E-gov) from an analysis of the discursive field of innovation in the public sector in Cape Verde from the point of view of Laclau and Mouffe's Discourse Theory. An instrumental case study was conducted using the reproduction method proposed by Glynos and Howarth and discourse analysis (French matrix). The aim was to unveil the phantasmatic logic of the discursive articulation of this social practice of the subjects that constituted the E-gov. The results show that although E-gov is an incomplete, vulnerable, and contingent entity, the identity of the agents involved in its discursive articulation depends on its capacity to reiterate the discourses of 'the information society,' 'E-government as a strategic option for development,' and 'state reform and administrative modernization' over time. However, E-gov has revealed itself as a discursive system impregnated with demands related to an occasional technicality and to the implicit belief of agents of the Cape Verdean public sector that the use of ICT by public institutions generates structuring advances in administrative modernization and social transformation.

Keywords: e-government; innovation in public management; discourse theory; discourse analysis.

\section{A lógica fantasmática do e-government e o discurso da inovação em Cabo Verde}

O objetivo deste estudo consiste em aprofundar as reflexões sobre o e-government (e-gov) a partir de uma análise do campo discursivo da inovação no setor público em Cabo Verde, sob a ótica da Teoria do Discurso (TD) de Ernesto Laclau e Chantal Mouffe. Por meio de um estudo de caso instrumental e usando o método da retrodução proposto por Jason Glynos e David Howarth e a análise do discurso (de matriz francesa) dos sujeitos que constituíram o e-gov, buscamos desvelar a lógica fantasmática da articulação discursiva dessa prática social. Os resultados mostram, por um lado, que, embora, o e-gov seja uma entidade incompleta, vulnerável e contingente, a identidade dos agentes envolvidos em sua articulação discursiva depende de sua capacidade de reiterar os discursos de "aposta na sociedade da informação", "e-government como opção estratégica para o desenvolvimento" e "reforma do Estado e modernização administrativa” ao longo do tempo. Por outro lado, o e-gov se revelou um sistema discursivo impregnado de demandas relacionadas a um tecnicismo ocasional e à crença implícita dos agentes do setor público cabo-verdiano de que o uso das tecnologias de informação e comunicação (TIC) pelas instituições públicas gera avanços estruturadores na modernização administrativa e na transformação social.

Palavras-chave: e-government; inovação na gestão pública; teoria do discurso; análise do discurso. 


\section{La lógica fantasmática del e-government y el discurso de la innovación en Cabo Verde}

El objetivo de este estudio consiste en profundizar las reflexiones sobre el e-gobierno (e-gov) a partir de un análisis del campo discursivo de la innovación en el sector público en Cabo Verde bajo la óptica de la Teoría del Discurso de Ernesto Laclau y Chantal Mouffe. Para ello, por medio de un estudio de caso instrumental y usando el método de retroducción propuesto por Glynos y Howarth y el análisis del discurso (de matriz francesa) de los sujetos que constituyeron el e-gov, buscamos desvelar la lógica fantasmática de la articulación discursiva de esa práctica social. Los resultados muestran, por un lado, que aunque el e-gov sea una entidad incompleta, vulnerable y contingente, la identidad de los agentes involucrados en su articulación discursiva depende de su capacidad de reiterar los discursos de 'apuesta en la sociedad de la información,' 'e-government como opción estratégica para el desarrollo' y 'reforma del Estado y modernización administrativa' a lo largo del tiempo. Por otro lado, el e-gov se reveló como un sistema discursivo impregnado de demandas relacionadas a un tecnicismo ocasional ya la creencia implícita de los agentes del sector público caboverdiano de que el uso de las TIC por parte de las instituciones públicas genera avances estructuradores en la modernización administrativa y en la transformación social.

Palabras clave: e-government; innovación en la gestión pública; teoría del discurso; análisis del discurso.

\section{INTRODUCTION}

The presence of technology in the organization of almost all social practices is one of the most striking features of contemporary societies, to the extent that the regimes of knowing and doing practically confuse one another under the technology sovereignty (Rensburg, Telukdarie, \& Dhamija, in press). In this context, knowledge is both a key input and output factor of innovation in public management, and a fundamental resource for the institutional dynamization of various innovation processes, which make its transformation imperative in new knowledge (Heeks, 2003; Klabi, Mellouli, \& Rekik, 2018).

These disruptions require the emergence of new models of public management and complex and innovative forms of institutional actions by governments (Secchi, 2009; Castro, Ferreira, \& Costa, 2019), and the adoption of new instruments and procedures that help public managers in responding to the transformations and demands of the societies (Palaco, Park, Kim, \& Rho, 2019). The problems of contemporary societies render the discourse of new management technologies inexorable, using existing tools in the universe of information and communication technologies (ICT) (Czamanski \& Broitman, 2017). Thus, these governments have been looking for alternative forms of intervention, by planning public policies for innovation and speeding up the creation and diffusion of innovative processes in the public sector (Arundel, Bloch, \& Ferguson, 2019).

The discourses of governments are aimed at streamlining their services that generate the conditions of possibility for the emergence and implementation of e-government projects (e-gov), guided by a logic of simplification and democratization of access of citizens and businesses to public services (Twizeyimana \& Andersson, 2019). In this study, inspired by the conception proposed by the United Nations (UN) and the American Society for Public Administration (ASPA), the concept of e-gov refers to the use of the worldwide web (WWW) for provision of government information and services to citizens (Verkijika \& DeWet, 2018).

Despite advances in e-gov, some governments have overlooked the fact that successful reorganization of back-office and front-office depends on the organic restructuring of governments and the availability of public services online-through policies, strategies, and actions-, and encouraging greater citizen 
participation and accountability (Stefanovic, Marjanovic, Delić, Culibrk, \& Lalic, 2016). The lack of diligence with these cases has led to the failure of many e-gov projects at many latitudes (Heeks, 2003).

According to Larsson and Gronlund (2016), many nations-states still cannot implement e-gov projects that adequately respond to particular social demands of this era. In part, according to Mauro, Cinquini, and Pianezzi (in press), this is because of factors such as the increased complexity of the public agenda and social problems, financial constraints, reliance on decisions by higher international government bodies or private organizations, besides clientelistic practices in public sector management, control of innovation activities by government agencies and centralized management of innovation systems.

Led by the discourse of increasing competitiveness and government effectiveness of certain political agents and governments, the projects implementing public sector innovation activities in Cape Verde also present their contradictions, with centralizing trends in innovation activities, nondemocratic and anti-pluralist practices of public management (O’Flynn, 2007). Given this, starting from the e-gov conception as the result of a discursive construction (Klabi et al., 2018), we propose to analyze it from the understanding of the fantasies articulated by the main social agents involved in the disputes for the fixation of meanings of this social practice in Cape Verde.

The boundaries or misalignments of e-gov need to be analyzed by investigating the discursive articulation processes that generate their conditions of possibility as social practice (Lee-Geiller \& Lee, 2019). For this study, and given its coherence with the theoretical and epistemological assumptions that support it, we adopted a conception of e-gov that recognizes it as a field of discursivity. Thus, it should be studied as a social practice that aims to guide certain symbolic developments, by getting consensus, given the innovative actions in public management, or even determined order and/or a desired social transformation (Canclini, 2019). With this in mind, we elaborated on the following guiding question of the study:

- What are the fantasies articulated by the relevant agents of e-gov in Cape Verde in the disputes for the fixation of meaning of this social practice?

As a policy of innovation in the public sector, e-gov results from discursive disputes, whereby certain (particular) groups seek to defend certain (particular) demands by making up their representations (Arundel et al., 2019). Therefore, it is with this conception of e-gov in mind that we opted for the theoretical contributions of Discourse Theory (DT), aiming to overcome the gaps that the analytical models of this phenomenon present, based on their development stages, and the limitations of innovation theories in organizational studies to understand the political issues surrounding it as a discursive social practice.

\section{THEORETICAL FOUNDATIONS}

\subsection{Laclau and Mouffe's Theory of Speech}

In Hegemony and Socialist Strategy, Laclau and Mouffe (1985) use post-structuralist thinking as an approach to political analysis in the strictest sense. This strategy enabled them to deconstruct many classic concepts of social and political thought, such as: ideology; power; order; emancipation;universality / 
particularity; and society/social (Kolvraa, 2018). We can say that poststructuralism came across what Marchart (2007) called the "political turn", from which the social and the identity of the subject are re-conceptualized, because of discursive articulations, besides defending the impossibility of society and an emancipatory project like modernity (Smith, 2012).

From this perspective, e-gov should be understood as the result of discourse articulations that are never fully conclusive, since its meaning cannot be definitively fixed (Fairclough, 2008). This paves the way for constant struggles (related to the definitions of this practice) involving the Capeverdean Operational Center for Information Society (NOSI) as one of the most relevant agents of the e-gov signification chain in Cape Verde, these struggles are related to the definitions of this practice in the country. The Discourse Theory (DT) is inserted in a "contemporary and post-structuralist matrix, which contemplates contingency, precariousness, indetermination and paradox as ontological dimensions of the social" (Mendonça \& Rodrigues, 2008, p. 26) and makes up a sophisticated theoretical framework for understanding the social, adopting power and discourse as central categories (Snir, 2017).

Laclau and Mouffe (1985, p. 105) define discourse as a "structured totality resulting from articulatory practice". This assumes the existence of a set of elements linked in a chain of equivalences and those excluded from that same chain (Snir, 2017). Within the discourse, the meaning is constructed in terms of equivalence and difference (metonymically or metaphorically), and in some situations, the logic of difference predominates, while in others the logic of equivalence prevails (Howarth, 2005). Most of the time, however, meanings are formulated both by affirming difference and by articulating chains of equivalence.

This conception reinforces our conviction regarding the explanatory capacity of DT, regarding the e-gov phenomenon, since it allows us to know its articulatory practices expressed in the clashes by fixing their meanings in the Capeverdean social context. In methodological terms, in the application of DT, we focus our efforts on exploring the phantasmatic logic to understand what the fantasies are and how they are articulated by the relevant agents of e-gov in Cape Verde in the disputes for the fixation of this social practice meanings.

\subsection{The Phantasmatic Logic}

Human being is a subject of desire, therefore possessing affection and imagination (Lacan, 2008). Therefore, the logic of fantasy theorizes the connection of the symbolic subject with something that is not of its (symbolic) meaning order (Salter, 2016): the real (of joy). This logic allows us to analyze the enjoyment (understood here as pleasure) that subjects seek in their discursive articulations of e-gov.

The logic of fantasy operates in the sense of enabling a form of ideological closure of the radical contingency of social relations and the naturalization of the different domination relations in which subjects engage (Howarth \& Griggs, 2012). In this view, fantasy is conceived as an imaginary scenario whose function is to provide a kind of positive support for filling the subject's constitutive gap (Ostermann, 2019). The same holds true for social fantasy, which comprises an imaginary scenario that fills the gaps in social structure, hiding its constitutive antagonism with the fullness of enjoyment. It is a necessary counterpart to the concept of antagonism (Laclau, 1990). 
Because fantasies make up an ideological illusion or forms of false consciousness (Glynos \& Howarth, 2007), they aid in the organization, even partially, of our perceptions of e-gov. As they embrace their radical contingency, fantasies help to structure our understanding of social relations in the discourse field of public sector innovation in Cape Verde. It is important to note, however, that the "success" of a given fantasy in this discursive arena depends on its invisibility, as phantasmatic figures and devices cease to function properly when they become visible (Clarke, 2011).

Phantasmatic logic concerns the force behind the signification operations and allows to explain both the inertia in maintaining practices and the speed of changes that occur in them (Salter, 2016). In social (or political) practices, fantasy operates to hide the radical contingency of social relations (Glynos, 2008). And it occurs when social agents use a phantasmatic or logical narrative that involves some reference to an idealized scenario, or a fullness to come, once a named obstacle (the beatific dimension of fantasy) is overcome, or a narrative that predicts disaster, if the named obstacle proves insurmountable (the horrible side of fantasy) (Lacan, 2008).

In this sense, if political reality comprises a symbolic construction, it certainly depends on fantasy to make up itself (Ostermann, 2019). Thus, the phantasmatic logic allows us to understand not only the nature of innovative actions in the Capeverdean public sector, as the discourses that articulate resistance to e-gov, but also to better understand the speed and direction of the discourses that underpin these innovations.

\subsection{E-gov in the context of New Public Management}

New Public Management (NGP) has become a widely used term in organizational studies and it describes a global trend towards a certain type of administrative reform (Mauro et al., in press). However, NGP takes on different meanings in different administrative contexts (Ashraf \& Uddin, 2016). For this study, it refers to the uniform and global movement of government reforms. The main feature of NGP reforms is the change in orientation from input to output (O'Flynn, 2007).

It is in this context that the notion of e-gov emerges as uninterrupted innovation in service delivery, citizen participation, and governance through changing internal and external relations using ICT, especially the internet (Lee-Geiller \& Lee, 2019). This requires a structural transformation in the logic underlying the state's administrative processes and procedures and a redefinition of the boundaries between that state, the citizen and other civil society actors, such as parastatal agents and non-governmental organizations (NGOs) (Klabi et al., 2018).

For Twizeyimana and Andersson (2019), e-gov is a technology-driven reform movement in which the reform strategy follows the potential created by modern ICTs. The centrality of the e-gov concept lies in using ICT in all areas where it is possible to rebuild the governance structure, redesign processes, computerize operational activities and provide better services to society (Czamanski \& Broitman, 2017).

The e-gov is eminently relational, as it is not restricted to implementing new technologies, but translates into the close connections between all government actors: citizens, suppliers and other governments (Palaco et al., 2019). It was with this in mind that we undertook this endeavor to understand e-gov as a discursive practice, based on the analysis of the fantasies articulated by the social actors involved with e-gov in the discursive disputes for the fixation of its meanings in Cape Verde. 


\section{METHOD ANALYTICAL PROCEDURES}

\subsection{Characterization and nature of research}

The ontological and epistemological perspectives of this research fit into the orientation of social constructionism (Berger \& Luekmann, 2004). We can better understand the nature of this study object under the auspices of the qualitative tradition (Godói, Bandeira-de-Mello, \& Silva, 2010). For the analysis of the phantasmatic logic of e-gov discursive articulation, we have adopted Frenchbased discourse analysis (AD) as the analytical procedure, once it provides a general framework for problem-oriented social investigation. We adopted the retroduction method (Glynos \& Howarth, 2007) to investigate which factors have historically created the conditions for the implementation, maintenance, and acceptance of the e-gov project in Cape Verde.

\subsection{Data Collection}

For this study, we define NOSI as the central subject of enunciation, considering its expressive representativeness in the discursive field under study, and it is the state agency that controls public sector innovation activities and its responsibility for the policy design, definition of strategies and implementation of actions related to e-gov and the information society in Cape Verde. However, the Cape Verde case is secondary and serves to help understand a broader phenomenon, e-gov, from a discursive perspective.

Flick (2006) recommends for qualitative research 4 basic types of data collection procedures, namely: a) observation; b) Interviews; c) documents; and d) audiovisual materials. Recognizing the relevance of these procedures, we use them all in the data collection, but always taking into consideration our intuitive judgments about their importance and significance for this study.

During the data collection period, we visited NOSI, during which we conducted some interviews and took part in meetings (as a non-participating observer) and e-gov-related events in Cape Verde. The observation also provided information that helped correct some inaccuracies during the interviews. We analyzed each note of observation as NO and the number following the letters corresponds to the sequence in focus (NO1, NO2, NO3 ...).

\subsection{Data Analysis}

We have organized and manage the data using NVIVO software, a computer program for qualitative data analysis which, besides being a text-based manager used for many electronic files, can be used for encoding and code retrieval in documents.

We conducted 15 interviews, 7 with NOSI employees, 4 with citizens using e-gov services, 3 with civil servants (from institutions other than NOSI), and 1 with a nation's congressperson. For our research, we favor data collection with the information systems coordinator, the manager, department coordinators, IT and multimedia department technicians, and the communication and image department technicians, business managers - a recent figure in the organic structure of NOSI, and other key players in the discursive field who are part of the articulatory chain as citizens using 
e-gov services, public servants of other ministries who were impacted by these services, and with political leaders involved in the state administrative restructuring.

In the interviews with these actors, our goal was to understand/unveil what meanings they attribute to e-gov in their discursive articulations and to understand their perception about NOSI's role in the public sector innovation in Cape Verde. We asked them about their political (articulations) actions, considering the control of innovation activities in the public sector by NOSI and the changes that these articulations may bring about in the organization of public institutions and the effects of these services on ordinary citizen's everyday life.

We know that these subjects may not have explained their actions or intentions, but we believe they have offered us insights into their practices in the incessant dispute over the e-gov significance.

To preserve the identity of the interviewees, we present only the initials of their first names and each interview was analyzed in the form of $(E)$, reference $(\$)$ and sequence of lines in focus, extracted from NVIVO after coding: E1, $\$ 1: 1-10$.

As for the questions of the qualitative interview, we grouped them into three types: a) the main ones; b) the exploratory ones; and c) the accompanying ones. We carry out a careful and consistent selection of official documents, legislation, and technical and official reports. We visited the UN website on public administration networks and the e-gov database worldwide and Cape Verde E-Regulations. During the analyses, each document was analyzed as an official document (DO) followed by the reference $(\$)$ in focus, extracted from NVIVO after coding: DO1, $\$ 1$.

The legislations (LG) were analyzed along with the reference $(\$)$ in focus, extracted from NVIVO after coding: LG1, $\$ 1$. The survey of the legislation covered the period from 1975 to 2012. The reports (RE) were analyzed along with the reference $(\$)$ in focus, extracted from NVIVO after coding: RE1, $\$ 1$. This report was published in 2014. In seeking to identify discursive practices outside the framework of hegemonic agents (and outside the institutional space), we resorted to the written press. We used 90 stories in the construction of the analytical corpus. The news (N) was analyzed along with the reference $(\$)$ in focus, extracted from NVIVO after coding: N1AS1, $\$ 1$. The journalistic and social media texts collected were published between 2010 and 2014. We selected 9 video reports published by NOSI and 19 news videos about e-gov in Cape Verde.

During the analyzes, this audiovisual material (MA) was analyzed along with the reference $(\$)$ in focus, extracted from NVIVO after coding: MA1, $\$ 1$. The survey of audiovisual material covered the period from 2010 to 2014 .

\section{RESULTS AND DISCUSSION}

\subsection{Unveiling the Phantasmatic Logic of Discursive Articulation}

The existence of a specific political and social context of the Republic of Cape Verde contributed to implementing e-gov and the creation of conditions for the possibility of introducing innovative actions in the Capeverdean public sector management.

Good governance and proper macroeconomic management, along with openness to trade and increasing integration into the global economy, and the adoption of effective social development 
policies, are part of the goals set by the World Bank (WB 2019) for developing countries. and underpinned a well-known development path of the country. These guidelines are in-between the mission defined for NOSI. For these management purposes, Cape Verde was accepted as a special partner of the European Union (EU) in November 2007, and in December of that year as a member of the World Trade Organization (WTO). In January 2008, the UN graduated it as "Middle Income Country", the second in sub-Saharan Africa to achieve this rise after Botswana, and the first graduation in more than a decade in Africa (Madeira, 2016; Monteiro, 2011).

NOSI has been inserted in this context since 1998 with the founding of the State Financial Administration Reform Unit (RAFE), an already extinct body, considered the e-gov embryo in Cape Verde. The RAFE project was limited to the Ministry of Finance, which had invested in introducing technology platforms and new ICT-based management mechanisms developed by young Capeverdean technicians to improve state financial management. The experiment was successful and gradually spread to other sectors of public administration, leading the government to create a cross-cutting and comprehensive unit for deep state reform and administrative modernization, with ICT as its foundation. NOSI was formally installed only in January 2004, on the premises of the Ministry of Finance building, in Plateau, the historic center of Praia (Resolution no. 15, 2003). NOSI activities cover all direct and indirect state administration, including municipal governments (Operational Nucleus for Information Society [NOSI], 2005a).

Over the years, the information systems coordinator has played a key role in establishing links between the manager and middle managers, and monitoring and overall coordination of projects that aim to put the citizen at the center of the service, take part in society modernization and economic growth, boosting the knowledge society, notably through innovation and integrated electronic governance mechanisms, to facilitate the daily lives of citizens and economic agents and raise the bar for competitiveness, and improving the Capeverdean's quality of life.

This context reinforces an ideology about this social practice, still under construction, which, from the perspective of discourse theory, functions as a fantasy seeking to fill the void that permeates social practices. This fantasy makes up an attempt to establish closure to various disputed issues in Capeverdean society.

The phantasmatic logic is based on the fantasies used by the Capeverdean government, both to sustain and perpetuate meaning-making practices and to engage different actors in society toward new projects. Through a narrative that promises fullness and overcoming obstacles, this logic acts to hide the political dimension and the contingency of social relations. Therefore, it plays a relevant role in the construction of equivalence chains, used by individuals to forge unity around a nations project from a multitude of positions (Glynos \& Howarth, 2007).

E-gov integrates the discourse of state reform and administrative modernization, so that its phantasmatic logic is linked to the domains of this discourse: its fantasies, mostly articulated in the media space, are related to: a) transformation of Cabo Verde into cyber islands; b) creation of an ICT cluster in Cabo Verde; and c) transformation of Cabo Verde into an international business center (Figure 1). Let's assign these categories an analytical imprint to help the analytics work. They are not mutually exclusive but rule the data ordering and simplify the conduct of analysis. 


\section{FIGURE $1 \quad$ PHANTASMATIC LOGIC OF E-GOV IN THE REPUBLIC OF CABO VERDE}

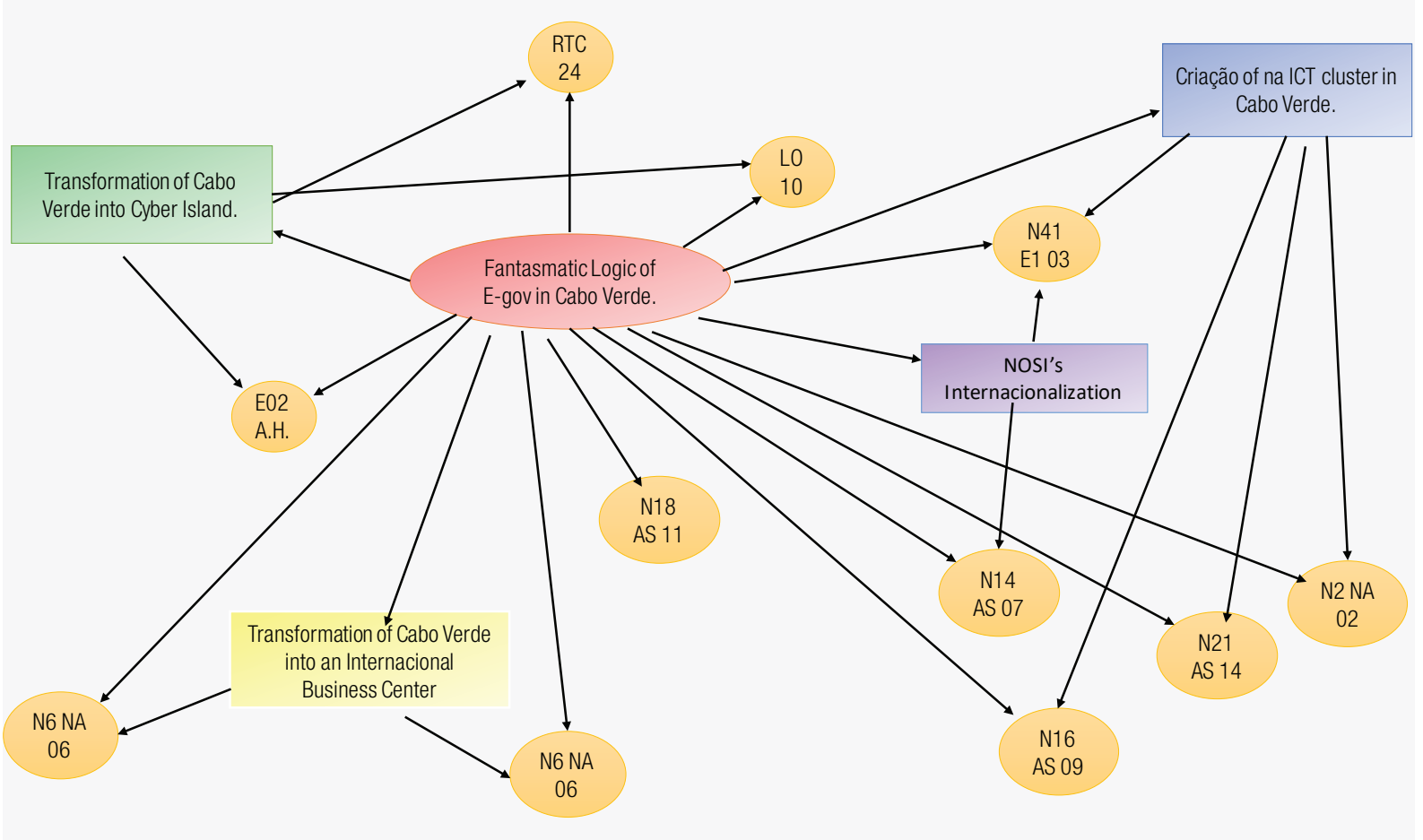

Source: Elaborated by the authors.

\subsubsection{Transformation of Cabo Verde into cyber islands}

The Capeverdean government uses the narrative that the control of (technological) innovation activities in the public sector through NOSI has enabled the generation of conditions for e-gov implementation, and to convince other social agents to adhere to their discourse of state reform and administrative modernization. He often articulates in his discourses the fantasy of Cabo Verde's transformation into cyber islands, as a strategy for boosting the ICT market in Cabo Verde and as a way of attracting large ICT multinationals, such as Huawei, which are seeking the African market. Here, for these multinationals, the country would act as a gateway to the African continent, as shown by the analytical corpus of this study:

Since e-gov, for us, is a product, why not turn Cabo Verde into cyber islands so that big corporations like Microsoft, Cisco, Oracle see Cabo Verde as a development point for their products, such as Have been to India, Mexico, and Ireland? We have great advantages, such as the geographical position, transparent governance, we have the human capacity right now to develop products and, above all, we are few, which is also an advantage. It is easier for large corporations to deploy their products in a market like ours (E02, \$2, pp. 188-198). 
We realize that these social actors create the idealized scenario of cyber islands to mount the discourse. This symbolic construction help in creating consensus to hide dissent and the radical contingency of social relations (Glynos, 2008). The fantasy of cyber islands should justify the venture that has the potential to fulfill the demands of public management and that should generate the conditions of possibility for the country's development.

With this discourse, one can show the need to overcome the Weberian bureaucratic model in the contemporary institutional context and the detachment of the fundamental assumptions for the country's development, now based on the development of the information technologies (Twizeyimana \& Andersson, 2019). In this way, they are aligned with the discourses of managerial public administration (APG) and entrepreneurial government (GE) or public governance (GP), which incorporate the narratives of innovative actions in public administration aimed at achieving productivity, orientation towards service, efficiency in service delivery, commodification, accountability and decentralization (Secchi, 2009).

The limits imposed by the articulation of relevant agents and their interests in the various contexts are hidden conditions for the fantasy's materialization (Salter, 2016). For example, regarding the fantasy of transformation of Cabo Verde into cyber islands, some agents of the articulatory chain antagonistic to e-gov discourse argue:

[...] the Government continues to show a mismatch on the vital telecommunications issue as regards, inter alia, the diversity, and quality of services provided, the costs involved and the potential implications of the sector on the national economy, one year after the presentation of the new Communications Act at the Parliament. And all of this, says Humberto Cardoso, "notwithstanding airborne phrases like Digital Praia, visionary proclamations of cyber islands, and obsessions like NOSI” (N70LO10, \$1-3, pp. 169-174),

We also must invest more in mobility, with solutions for PDAs, smartphones, etc. The idea is to make e-gov mobile, which will be a big step, as citizens will use public services wherever they are. But to get to cyber islands, we have a lot to do. At this point, we depend on strategic rather than technical issues (E02, \$2, pp. 202-206).

Despite the antagonisms, the existence of the social actors involved in the discursive disputes related to e-gov and the fixation of meanings of this practice in Cape Verde, the meaning of e-gov has been constructed in terms of equivalence rather than of difference (Howarth, 2005). The fantasy of transforming Cape Verde into cyber islands also represents a symbolic construct to signify e-gov as the social practice that will enable the transformation of the public service delivery logic of and the use of new ICTs to leverage the competitiveness of the Capeverdean economy.

The power of this fantasy has its roots in ancient analyzes, such as Osborne and Gaebler (1992), when they created the term "entrepreneurial government" as a pragmatic style of public management and showing the benefits of public management reforms through combining innovation with the use of ICT tools. These scholars emphasized the need for the development of more effective governance and organizational arrangements that would facilitate increased capacity for state- 
provided services. More than introducing electronic versions of existing services, these actions require the configuration of information architectures that can be exploited through and within new service channels.

\subsubsection{The creation of an ICT cluster in Cabo Verde}

Because of the fantasy 'creation of an ICT cluster in Cape Verde', the relevant agents in e-gov discursive articulation seek to link a range of possibilities and new challenges to this practice, in economic terms and the governance paradigm, in search of the hegemonization of his discourses (Laclau, 1990). In this sense, it can be stated that the discourse of state reform and administrative modernization, through e-gov, comprises an idealized imaginary of profitable business with ICT (Czamanski \& Broitman, 2017), based on a technology park installed in the city of Praia, in Cabo Verde, capable of bringing financial compensation, according to international parameters.

The Capeverdean data center will host a service intelligence platform. According to the NOSI manager, the agreement involves, besides a mutually helpful partnership relationship, a profitable business dimension, whose compensation for the Capeverdean institution is following international parameters in such transactions:

The signing of the agreement was a historic moment because it marks the beginning of the operationalization and monetization of the Data Center, one pillar of the Technology Center. Thus, "these pillars are based on the implementation of the Cape Verdean Government's strategy of creating a cluster of information and communication technologies in Cabo Verde" (N16AS09, $\$ 1-2$, pp. 28-38).

The discursive logic of the cluster should allow this series of experiments and practices such as a profitable business and strategic partnerships from the Cabo Verde Islands, which end up creating a benign movement to create the necessary consensus to make this venture possible. In Wittgenstein's (2005) terms, it is a context that creates a discursive logic that makes it possible to highlight and justify their practices. The creation of the cluster opens the door to incorporate the discourses of the new institutional economy and managerialism into public sector reforms (Mauro et al., in press).

Thus, the generation of this discursive logic of 'creation of ICT cluster in Cabo Verde' is enough to capture the nature of the articulations in the relationship between NOSI and the various protagonists that regulate and execute the actions around e-gov in Cape Verde. From this position, one can characterize the discursive articulations of e-gov and highlight the efforts for its viability or cancellation:

The cluster has a beginning, but it has no end, it is a process. Just because we are now starting to talk about the cluster, this does not mean that we are just now beginning its construction. The cluster has been built for a few years now. Today, perhaps, we have a more institutionalized concern to better tidy up the puzzle pieces: companies, academy, but we still must work hard, improve a lot. So, I think we are shaping the cluster and I think we have a potential for national 
capacity that, if well worked, with humility but a lot of determination, we can go far. We can make information and communication technologies a sector that can contribute to national wealth (N21AS14, \$3, pp. 90-97).

This excerpt testifies that e-gov phantasmatic logic is sustained, in the terms of Glynos and Howarth (2007), in an idealized context of technological processes in the agenda of state reform and administrative modernization, which can contribute to the construction of a more competitive economy, free of bureaucracy, based in intensive use of ICT. This logic also articulates the question of cluster internationalization, which is the demand most often articulated by NOSI and is linked to the fantasies of this project creation and the transformation of the country into an international business center.

\subsubsection{International Business Center}

The ideal of creating an ICT cluster in Cape Verde is associated with the idea of transforming Cape Verde into an international business center. The government has created a supervisory committee that includes representatives of the Agency for Business Development and Innovation (ADEI), the Association of Young Entrepreneurs (AJEC), the City Council of Praia (CMP), the Sotavento and Barlavento Chambers of Commerce (CCS / B) and the Bank of Cabo Verde (BCV), to oversee and ensuring the implementation of the Capeverdean technology park, a project designed to transform the archipelago into the mentioned international business center:

Speaking recently to the Lusa agency, the park's Master Plan coordinator and the Information Society Operational Center (NOSI) manager, Jorge Lopes, showed that the space is a "complex to foster economic, entrepreneurial and scientific and technological research growth". The aim is to provide Cabo Verde with a world reference space in the ICT framework, in an international service center, to enhance the development, visibility and commercialization of e-gov, e-education, and financial services, to foster a climate of innovation and technological entrepreneurship and establish partnerships with leading international players in the sector. The space will feature several valences, including multipurpose offices, a congress center, business incubation spaces, training, and qualification rooms and common services such as restaurants, hotels and leisure and sports areas, and offices (N49EI05, \$2, pp. 149-161).

The fantasy of 'NOSI internationalization' urged several social agents to adhere to the e-gov discourse, especially articulated by NOSI. This is because of the institution's experience in technological innovation in the public sector with e-gov projects and technologies in several African countries, which makes it seem as an agent capable of opening market doors to small Capeverdean ICT companies. Thus, the fantasy of NOSI internationalization had a strong influence on the engagement of social agents, in the sense of perpetuating the discourse of state reform and administrative modernization (Ashraf \& Uddin, 2016): 
The technology park will be the instrument of NOSI internationalization. The idea here is: since Cape Verde dominates some technologies, it has already had some exposure take the theme that has the most international projection, e-gov, find a physical space that we can identify with this theme and create an entire ecosystem to take it out. With the private sector here complementing e-gov products, from Cape Verde's, we will set up research and certification centers and we will improve this governance business, of better government. Let's use this to export. So, the technology park is this, taking the e-gov theme and getting Cape Verde to export services (E1, pp. 401-410).

The NOSI internationalization fantasy boosted the agents around the e-gov discourse that glimpsed future ICT business possibilities with the build of new data center and technology park. Our analyses show that, in Cape Verde, e-gov is a recent social practice whose equivalences, differences and fantasies articulated in disputes over its meaning / constitution reveal an attempt to hegemonize the idea that the introduction and use of ICTs in public institutions allow them to transform themselves into self-centered conglomerates in technologized administrative apparatuses aimed at the citizen.

The e-gov meaning by their relevant agents as electronic information and electronic governance show their concerns about the association of this practice with rationalization and transformation through ICTs and public services delivery structures in detriment of innovations that can improve substantially the quality of public services and governance process (Lee-Geiller \& Lee, 2019).

At the heart of the public sector innovation process diffusion through e-gov, lies information exchange about innovation and experience among public networked institutions (Palaco et al., 2019). In this non-linear and communication and learning complex process, these institutions decrease uncertainties about certain innovations. However, the results allow to state that differences in the e-gov discourses and the meanings assigned to this practice justify the integration difficulties between back-offices of the different institutions that make up the Capeverdean public sector and contribute to the increase of uncertainties regarding the innovations produced / inserted by NOSI in this sector after implementing e-gov.

For Klabi et al. (2018) the non-integration between the different back-offices don't allow the share of information's about innovations between public Capeverdean institutions, this turn more difficult to form a new equivalence chain around distinct e-gov discourses and meanings which had articulated by the social agents, and the relevant paper of this practice for innovative actions development and public sector entrepreneurial activities.

The e-gov meaning as electronic governance and electronic information lead communication and learnship between public institutions to not be understood as an interactive process that they express, test and regroup the e-gov discourses (Czamanski \& Broitman, 2017). It occurs because the relevant agents articulated in e-gov discourses search, according to Laclau (2006), the hegemonization of government interests in state reform and administrative modernization from electronic public services setup.

The core of discussion addresses technologic aspects and the policy question is treated secondarily, once that it difficult innovative action planning in public sector and for the public policy elaboration, 
which embraces the development and implementation of e-gov projects and innovative systems management, especially in Republic of Cape Verde context:

The government has been betting in electronic governance. This bet is imperative to improve the State's effectiveness and public administration, both centrally and locally, reinforcing Democratic Rule of Law, once the information technology help to improve the accountability and democracy $(\mathrm{DO} 3, \$ 13)$.

The Electronic Government is one pillar of Informational Society development in Cape Verde, according to established in the Strategic Program of Information Society (SPIS) (DO3, \$6).

These shreds of evidence show that we are dealing with a scenario which innovative activities control in public sector is under command of a single government agency in which public managers face difficulties to promote a transition from an institutional culture with traits of patrimonialism and bureaucratism to another that is efficient and effectively democratic, that define clear accountability patterns.

Despite it, on the one hand, the existence of a trend - undemocratic and anti-pluralist - growing the control of innovative activities and innovative systems management centralization. Because none of the current analytical models can embrace enough to build a theoretic reference framework for the advance of studies about e-gov, as growing expectations about ICT contribute to administrative modernization relighted the discussion about e-gov on the field of innovation in public sector and in the public management itself.

\section{FINAL CONSIDERATIONS}

The purpose of this research emerged from the opportunity for analyzing the phantasmatic logic from the problematization of the empiric fact: the e-gov in Cape Verde. Therefore, we adopted the Glynos and Howarth (2007) retroduction method intending to reject the concept of e-gov as a founding totality of their partial processes and conceive it as a social practice emerging from discursive construction, always contingent. The problematic of this study emerging from this discussion can be expressed as follows:

- What are the fantasies articulated by relevant agents of e-gov in Cape Verde in the disputes for meanings fixation of this social practice?

We found that, in Cape Verde, e-gov is a discursive system full of demands related to occasional technicality moved by implicit government belief in a progression in administrative modernization and social transformation from ICT-based technological innovations. This demand reflects the form that ICT is perceived and absorbed by the public institutions and reveal also the server's subordination, working methods, and skills of these institutions to NOSI and the government through such technologies. 
Thus, to highlight conclusive aspects and answer the central question of the study, we can state that the phantasmatic logic of e-gov (logic despite to strength behind the operations of meanings e-gov) is linked essentially to State reform and administrative reform discourse. The "Cape Verde transformation in cyber islands" fantasy, and the "ICT cluster creation in Cape Verde", and "transformation of Cape Verde into international business center" are articulated by government and by NOSI, relevant e-gov agents, particularly on media space and aims the engagement by another social agents around public sector innovative projects under e-gov.

The transformation fantasy of Cape Verde in cyber islands embrace the promise of a technology park creation in the city of Praia and its metamorphosis in a kind of Capeverdean Silicon Valley, a project whose wingspan will bring business opportunities as ICT, including major international players from this segment, like Huawei, which see Cape Verde as most growing gateway for ICT market - the African. However, the limits imposed by the relevant agents of counterhegemonic e-gov chain and their interests in many contexts reveal overcast materialization of fantasies conditions. For example, the MPD, the main opposition political party consider the fantasy of "Cape Verde transformation in cyber islands" represents nothing over one more strategy for the transformation of public service logic provision and benefit even more the NOSI in innovation on the public sector.

The "fantasy of creating an ICT cluster in Cape Verde" engages private companies more in the area around the government-articulated state reform and administrative modernization discourse, which comprises an idealized environment with a wide range of business possibilities from these companies with public institutions.

The e-gov phantasmatic logic in Cape Verde is based on an idealized scenario of technological processes, within the framework of state reform and administrative modernization, which can contribute to the generation of business in the ICT sector and, the use of these ICTs to improve the country's competitiveness index. Hence the link between the fantasy of creating an ICT cluster in Cape Verde and the fantasy of transforming Cape Verde into an international business center and the internationalization of NOSI.

NOSI experience with technological innovation projects within e-gov in Cape Verde and some other African countries (Mozambique, Guinea-Bissau, Equatorial Guinea) makes the fantasy of its internationalization propel social agents to join their speeches/projects and those of the government. Therefore, the results show that the process of adoption/implementation of ICT in innovation processes in the public sector depends on political articulations and, on social and technical contingencies, such as the types of systems introduced, who will control them and the type of infrastructure dedicated to their support.

An important implication of the results is the need for understanding by relevant e-gov agents that individual status concerning technology systems is superior or at least as important as ICT-supported working procedures in management. Also, in testing and refining innovation programs within e-gov, relevant actors must remember their discourses and policy practices directly reflectes in management and innovation practices in the public sector.

Finally, we problematize the social practice studied from the ghostly logic, which addresses the ideologies present in the discursive articulations, and, in line with the methodological proposal of 
RAP | The phantasmatic logic of e-government and the discourse of innovation in Cape Verde

the back production, we evaluate the discourses that make up the e-gov in Cape Verde. But discussion bridges can be worked with other conceptual fields in which they can clarify the object of study. In this same theme, one can discuss the social logic of e-gov, including its dominant meanings in the articulations in the institutional and media spaces, and the norms, policies, rules, and self-representations that make up it. The e-gov political logic can also be incorporated by addressing the discursive practices that generate the chain of equivalences in their meaning, focusing primarily on the conflicts and contestations inherent in this practice.

By focusing on the fantasies built around e-gov, we leave out the tensions that exist between the internal operational efficiency of public institutions and the quality of the services they provide, requiring future studies to shed light on issues related to reducing transaction costs. Citizen / client and increasing the speed of processing demands for services, with a view of encouraging public servants to focus on quality in service delivery. 


\section{REFERENCES}

Arundel, A., Bloch, C. \& Ferguson, B. (2019). Advancing innovation in the public sector: aligning innovation measurement with policy goals. Research Policy, 48(3), 789-798.

Ashraf, J., \&Uddin, S. (2016). New public management, cost savings and regressive effects: a case from a less developed country. Critical Perspectives on Accounting, 41, 18-33.

Banco Mundial. (2019). Cabo Verde: aspectos gerais. Retrieved from http://www.worldbank.org/pt/ country/caboverde/overview

Canclini, N. G. (2019). A culture of informality. Urban Studies, 56(3), 488-493.

Castro, J. C., Ferreira, M. O. \& Costa, M. F. (2019). Estratégias de políticas públicas para redução da informalidade no setor de confecções: aplicação do método de análise hierárquica. Future Studies Research Journal, 11(2), 176-196.

Clarke, M. (2011). Talkin' 'bout a revolution: the social, political, and fantasmatic logics of education policy. Journal of Education Policy, 27(2), 173-191.

Czamanski, D., \& Broitman, D. (2017). Information and communication technology and the spatial evolution of mature cities. Socio-Economic Planning Sciences, 58, 30-38.

Fairclough, N. (2008). Discurso e mudança social. Brasília, DF: Ed. UnB.

Flick, U. (2006). An introduction to qualitative research. London, England: SAGE.

Glynos, J. (2008). Ideological fantasy at work. Journal of Political Ideology, 13(3), 275-296.

Glynos, J., \& Howarth, D. (2007). Logics of critical explanation in social and political theory. New York, NY: Routledge.

Godói, C. K., Bandeira-de-Mello, R., \& Silva, A. B. (Orgs.). (2010). Pesquisa qualitativa em estudos organizacionais: paradigmas, estratégias e métodos (2a ed.). São Paulo, SP: Saraiva.

Heeks, R. (2003). E-government in Africa: promise and practice. Information Polity, 7(2-3), 97-114.

Howarth, D. (2005). Applying discourse theory: the method of articulation. In D. Howarth, \&
J. Torfing (Eds.), Discourse theory in European politics: identity, policy and governance (pp. x-y). New York, NY: Palgrave Macmilan.

Howarth, D., \& Griggs, S. (2012). Poststructuralist policy analysis: discourse, hegemony, and critical explanation. In F. Fisher, \& $\mathrm{H}$ Gottweis. The argumentative turn revisited: public policy as communicative practice (pp. $\mathrm{x}-\mathrm{y}$ ). Durham, England: Duke University Press.

Klabi, H., Mellouli, S. \& Rekik, M. (2018). A reputation based electronic government procurement model. Government Information Quarterly, 35(4), 43-53.

Kolvraa, C. (2018). The discourse theory of Ernesto Laclau. In R. Wodak, \& B. Forchtner (Eds.), The Routledge handbook of language and politics (pp. x-y). New York, NY: Routledge.

Lacan, J. (2008). A lógica do fantasma. Recife, PE: Centro de Estudos Freudianos do Recife.

Laclau, E. (1990). New reflections on the revolution of our time. London, England: Verso.

Laclau, E. (2006). La razón populista. México, DF: FCE, 2006.

Laclau, E., \& Mouffe, C. (1985). Hegemony and socialist strategy: towards a radical democratic politics. London, England: Verso.

Larsson, H., \& Gronlund, A. (2016). Sustainable eGovernance? Practices, problems and beliefs about the future in Swedish eGov practice. Government Information Quarterly, 33(1), 105-114.

Lee-Geiller, S., \& Lee, T. (2019). Using government websites to enhance democratic e-governance: a conceptual model for evaluation. Government Information Quarterly, 36(2), 208-225.

Madeira, J. P. (2016). Cabo Verde: de um "Estado inviável" ao pragmatismo na política externa. Revista de Relaciones Internacionales, Estrategia y Seguridad, 11(1), 85-101.

Marchart, O. (2007). Post-foundational political thought: political difference in Nancy, Lefort, Badiou and Laclau. Edinburgh, Scotland: Edinburgh University Press.

Mauro, S. G., Cinquini, L., \& Pianezzi, D. (in press). New Public Management between reality and 
illusion: analysing the validity of performance-based budgeting. The British Accounting Review.

Mendonça, D., \& Rodrigues, L. P. (2008). Pósestruturalismo e teoria do discurso: em torno de Ernesto Laclau. Porto Alegre, RS: Ed. PUCRS.

Monteiro, M. I. G. (2011). Parceria especial Cabo Verde/União Europeia-UE: uma mudança de paradigma nas relações entre Cabo Verde e UE? (Master Thesis). Lisboa, Portugal: Universidade Técnica de Lisboa.

Núcleo Operacional da Sociedade da Informação. (2005a). Plano de Acção para a Governação Electrónica: uma governação mais próxima dos cidadãos. Praia, Cabo Verde: Alfa Comunicações.

Núcleo Operacional da Sociedade da Informação. (2005b). Programa Estratégico para a Sociedade de Informação: novas oportunidades de desenvolvimento. Praia, Cabo Verde: Book RJ.

O'Flynn, J. (2007). From new public management to public value: paradigmatic change and managerial implications. Australian Journal of Public Administration, 66(3), 353-366.

Osborne, D., \& Gaebler, T. (1992). Reinventing government: how the entrepreneurial spirit is transforming the public sector. Reading, MA: Addison-Wesley.

Ostermann, F. (2019). Applying discourse theory and interpretive policy analysis on foreign policy: the case of the French engagement in the Libyan War. SAGE Research Methods Cases. Retrieved from https://dx.doi.org/10.4135/9781526478016

Palaco, I., Park, M. J., Kim, S. K., \& Rho, J. J. (2019). Public-private partnerships for e-government in developing countries: an early stage assessment framework. Evaluation and Program Planning, 72, 205-218.

Rensburg, N. J. V., Telukdarie, A., \& Dhamija, P. (in press). Society 4.0 applied in Africa: advancing the social impact of technology. Technology in Society.

Resolução n. 15, de 7 de julho de 2003. (2003). O enquadramento institucional da actividade do Governo no domínio da sociedade de informação e do governo electrónico. Praia, Cabo Verde.

Salter, L. (2016). Populism as a fantasmatic rupture in the post-political order: integrating Laclau with Glynos and Stavrakakis. Kotuitui: New Zealand Journal of Social Sciences Online, 11, 116-132.

Secchi, L. (2009). Modelos organizacionais e reformas da administração pública. Revista de Administração Pública, 43(2), 347-369.

Smith, A. M. (2012). Laclau and Mouffe: the radical democratic imaginary. London, England: Routledge.

Snir, I. (2017). Education and articulation: Laclau and Mouffe's radical democracy in school. Ethics and Education, 12(2), 351-363.

Stefanovic, D., Marjanovic, U., Delić, M., Culibrk, D., \& Lalic, B. (2016). Assessing the success of e-government systems: an employee perspective. Information \& Management, 53(6), 717-726.

Twizeyimana, J. D., \& Andersson, A. (2019). The public value of e-government: a literature review. Government Information Quarterly, 36(2), 167-178.

Verkijika, S. F., \& DeWet, L. (2018). A usability assessment of e-government websites in SubSaharan Africa. International Journal of Information Management, 39, 20-29.

Wittgenstein, L. (2005). Investigaciones filosóficas. São Paulo, SP: Vozes. 


\section{Osíris Luís da Cunha Fernandes}

https://orcid.org/0000-0003-4158-6995

$\mathrm{PhD}$ in Business Administration from the Federal University of Pernambuco (UFPE); Marketing and Operations Director of the Pernambuco Institute of Technology (ITEP). E-mail: osiriscunha@gmail.com

\section{Fernando Gomes de Paiva Júnior}

https://orcid.org/0000-0001-5715-3882

$\mathrm{PhD}$ in Business Administration from the Federal University of Minas Gerais (UFMG); Professor of the Graduate Program in Administration of the Federal University of Pernambuco (PROPAD/UFPE); Coordinator of the Creative Economy Research Locus Research Group. E-mail: fernando.paivajr@pq.cnpq.br

\section{Nelson da Cruz Monteiro Fernandes}

iD

https://orcid.org/0000-0002-1662-9300

$\mathrm{PhD}$ in Business Administration from the Federal University of Pernambuco (PROPAD/UFPE); UFPE Focal Point in the Postgraduate Program in Intellectual Property and Technology Transfer for Innovation (PROFNIT/ UFPE); the Postgraduate Program in Management, Innovation and Consumption (PPGIC/UFPE), Campus Caruaru. E-mail: cruzfernandes55@gmail.com

\section{Marconi Freitas da Costa}

https://orcid.org/0000-0001-9888-8359

$\mathrm{PhD}$ in Business Administration from the University of São Paulo (FEA/USP); Vice Coordinator of the Graduate Program in Management, Innovation and Consumption (PPGIC/UFPE), Campus Caruaru; Permanent Professor of the Graduate Program in Administration (PROPAD/UFPE), Campus Recife. E-mail: marconi.fcosta@ufpe.br 